Jurnal Gizi dan Dietetik Indonesia (Indonesian Journal of Nutrition and Dietetics) Vol. 8, No. 2, 2020: 93-100
Available online at: http://ejournal.almaata.ac.id/index.php/IJND DOI : http://dx.doi.org/10.21927/ijnd.2020.8(2).93-100

\title{
The role of sodium intake and liquid balance to overcoming breathing based on respiration rate (RR) on congestive heart failure (CHF) patients
}

\author{
Rijanti Abdurrachim ${ }^{1 *}$, Nana Chairunnisa ${ }^{2}$ \\ ${ }^{1}$ Department of Nutrition in Health Polytechnic Banjarmasin, Jalan Haji Mistar Cokrokusumo No. $1 \mathrm{~A}$ \\ Banjarbaru Banjarmasin \\ ${ }^{2}$ Staf In Dr. H. Moch. Ansari Saleh Banjarmasin Hospital , Jalan Brigjend H. Hasan Baseri Km.2 \\ Kota Banjarmasin, Kalimantan Selatan \\ ${ }^{*}$ Corresponding author : rijanti63@yahoo.com
}

\begin{abstract}
ABSTRAK
Latar Belakang : Congestive Heart Failure (CHF) merupakan ketidakmampuan jantung memompakan darah untuk memenuhi kebutuhan oksigen dan nutrisi ke jaringan tubuh. Gejala kekambuhan tersering adalah sesak napas. Salah satu penatalaksanaan diet pasien CHF adalah pembatasan natrium dan cairan. Tujuan : Tujuan penelitian untuk mengetahui peranan asupan natrium dan keseimbangan cairan terhadap kejadian sesak napas berdasarkan Respiration Rate (RR) pada pasien Congestive Heart Failure (CHF) di Ruang Rawat Inap Jantung RSUD H. Moch. Ansari Saleh Banjarmasin.

Metode : Jenis penetian ini adalah observasional analitik dengan pendekatan prospektif. Populasi adalah semua pasien CHF yang dirawat inap di Ruang Berlian dan Ruang Kumala Lantai 3 RSUD H. Moch. Ansari Saleh Banjarmasin dari tanggal 16 April sampai 6 Mei 2018. Sampel adalah 12 orang diambil berdasarkan kriteria inklusi dan eksklusi. Cara pengumpulan data menggunakan formulir food recall $1 \times 24$ jam, formulir cairan dan formulir Respiration Rate. Analisis data menggunakan uji korelasi rank Spearman dengan tingkat kepercayaan 95\%.

Hasil : 12 responden diperolah 58.3\% berumur 56-65 tahun, 66.7\% berjenis kelamin laki-laki, dan 50\% dengan pendidikan SMP dan SMU/Sederajat. Pengkajian gizi pasien CHF yaitu sesak napas berkurang, tekanan darah menurun, data laboratorium normal, dan tidak ada perubahan diet yang diberikan. Asupan natrium cukup (75\%), tingkat keseimbangan cairan negatif $66.7 \%$, kejadian sesak napas berdasarkan RR normal (50\%) dan takipnea (50\%).

Kesimpulan : Terdapat hubungan asupan natrium $(p=0.049)$ dan keseimbangan cairan $(p=0.01)$ terhadap kejadian sesak napas berdasarkan nilai RR pasien CHF di Ruang Rawat Inap Jantung RSUD Dr.H.Moch.Ansari Saleh Banjarmasin. Pengaturan asupan natrium dan keseimbangan cairan berguna untuk mengurangi gejala sesak napas pada pasien CHF.
\end{abstract}

KATA KUNCI : congestive heart failure (chf); asupan natrium; keseimbangan cairan; sesak napas

\begin{abstract}
Background: Congestive Heart Failure (CHF) is the inability of the heart to pump blood to meet the needs of oxygen and nutrients to the body's tissues. The most common symptom of recurrence is shortness of breath. One of the dietary management of CHF patients is the limitation of sodium and fluid.

Objectives: The aim of the study was to determine the role of sodium intake and fluid balance in the occurrence of shortness of breath based on Respiration Rate (RR) in Congestive Heart Failure (CHF) patients in Cardiac Hospitalization at H. Moch. Ansari Saleh Banjarmasin.

Methods: This type of determination is an observational analytic with a prospective approach. The population was all CHF patients who were hospitalized in the Diamond Room and Kumala Room 3rd Floor RSUD H. Moch. Ansari Saleh Banjarmasin from April 16 to May 6, 2018. Samples were 12 people taken based on inclusion and exclusion criteria. How to collect data using a 1x24 hour food recall form, a liquid form and a Respiration Rate form. Data Analyst is using the Spearman rank correlation test with a $95 \%$ confidence level.
\end{abstract}




\begin{abstract}
Results : 12 respondents obtained $58.3 \%$ aged $56-65$ years, $66.7 \%$ male sex, and $50 \%$ with junior and senior high school education or equivalent. The nutritional assessment of CHF patients is reduced breathlessness, decreased blood pressure, normal laboratory data, and no changes in dietary material were given . A sufficient sodium intake (75\%), a negative fluid balance level of $66.7 \%$, occurrence of shortness of breath based on normal RR (50\%) and tachypnea (50\%).

Conclusion : There is a correlation between sodium intake $(p=0.049)$ and fluid balance $(p=0.01)$ to the occurrence of shortness of breath based on the RR value of CHF patients in the Cardiovascular Inpatient Hospital Dr.H.Moch.Ansari Saleh Banjarmasin.Adjusting sodium intake and fluid balance is useful to reduce symptoms of shortness of breath in CHF patients.
\end{abstract}

KEYWORDS : congestive heart failure (chf), sodium intake, fluid balance, shortness of breath

Article info:

Article submitted on May 28, 2020

Articles revised on June 20, 2020

Articles received on July 29, 2020

\section{INTRODUCTION}

Congestive Heart Failure (CHF) is the inability of the heart to pump blood to meet the needs of oxygen and nutrients to body tissues.(1)According to data from the World Health Statistics (WHS) in the World Health Organization (WHO) in 2012 stated that of 57 million deaths from all types of diseases, 36 million of them were caused by Non-Communcable Disease (NCD), which is cardiovascular disease, with the number of deaths from congestive heart failure in the amount of 17 million. (2)

From the report of the medical records at the H. Moch. Ansari Saleh Hospital, data on Congestive Heart Failure (CHF) was included in the 10 most diseases. In January-December 2016 showed amount patients failing heart congestive hospitalization in as many 267 patients and in mid- 2017 that the month of JanuaryJuly showed the number of patients with the disease failed to heart congestive many as 114 patients. (3)

The quality and survival of people with congestive heart failure is greatly influenced by proper diagnosis and management. To carry out the proper management, assessment data is needed on patients, one of which is nutritional assessment data. Nutrition assessment is an activity of collecting and integrating and analyzing data to identify nutritional problems related to aspects of nutrient and food intake, clinical aspects and behavioralenvironmental aspects and their causes. (4)

CHF patients who often return for hospitalization due to recurrence in $\mathrm{CHF}$ episodes. One symptom of recurrence that is often experienced by $\mathrm{CHF}$ patients is shortness of breath or often called dyspnea. According to Suratinoyo, et al (2016). (5) In patients with congestive heart failure often have difficulty maintaining oxygenation so they tend to be short of breath. People with heart disease and shortness of breath often experience disorders of the heart rhythm. Sometimes the heart unwittingly races quickly. In shortness of breath breathing frequency increases above 24 times per minute.

The results of a preliminary study conducted in the inpatient ward of Heart patients (Diamond Room and Ruby Room) H.Moch Ansari Saleh Hospital Banjarmasin on September 25, 2017 obtained data that from $5 \mathrm{CHF}$ patients treated, 2 of them were patients who were previously within the span of 3 last month had received treatment in the same room, where the length of stay of patients is between 5-7 days. Based on the medical record status, it is known that patients coming to the hospital complained of shortness of breath that was shown with objective data of respiratory frequency above 24 times / minute. (3)

Besides pharmacological therapy, nonpharmacological therapy can be done with fluid 
restriction, weight loss, low salt and low cholesterol diet, no smoking, exercise. (6)signs and investigations required to establish a diagnosis of heart failure, and those which will influence therapy or provide important prognostic information. It also gives guidance on the treatment, monitoring and support of patients with heart failure. Copyright $\odot$ 2003, Royal College of Physicians of London.","author":[\{“droppingparticle":"',",family":"'(UK Sodium restriction is intended to prevent, regulate or reduce edema, and reduce shortness of breath. Many patients with heart failure only limit the salt in their food ranges from 3 grams a day or 1000-2000 milligrams of sodium . According Kasron (2012) .(7) Excess fluid volume due to the amount of fluid collected in the interstitial result in peripheral edema, ascites, and as a result of heart failure, the supply of oxygen in the lungs fail, causing penim Bunan fluid in the lungs that can reduce the exchange of $\mathrm{O}_{2}$ and $\mathrm{CO}_{2}$ in the lungs, this will cause dyspnea with rapid and shallow breathing characteristics, so it is necessary to monitor the fluid balance. Because there is an increase in fluid in the CHF client, the fluid needs in the CHF client must be reduced from normal requirements. Fluid requirements for $\mathrm{CHF}$ clients are: $25 \mathrm{ml} \times \mathrm{kg} \mathrm{BW}$. This study aims to analyze the relationship of sodium intake and fluid balance to the occurrence of shortness of breath based on the Respiration Rate (RR) in Congestive Heart Failure (CHF) patients in the Cardiac Inpatient Room of H.Moch Ansari Saleh Hospital Banjarmasin in 2018.

\section{MATERIALS AND METHODS}

This type of determination is an observational analytic with a prospective approach. The population was all CHF patients who were hospitalized in the Diamond Room and Kumala Room 3rd Floor RSUD H. Moch. Ansari Saleh Hospital Banjarmasin from April 16 to May 6, 2018. Samples were 12 people taken with saturated sampling based on inclusion and exclusion criteria. The method of collecting data uses a 1x24 hour food recall form, a liquid form and a Respiration Rate form . Data analysis uses the Spearman rank correlation test with a $95 \%$ confidence level.

\section{RESULTS}

Table 1 shows that most respondents aged 56-65 years were 7 people (58.3\%). Based on sexes found men as many as eight people $(66.7 \%)$. Based on the study that respondents were Education junior I equal as many as six people (50\%) and were senior high school/equivalent as many as six people $(50 \%)$.

Table 2 shows, of the 12 respondents who had adequate sodium intake of 9 people $(75.0 \%)$, negative fluid balance of 8 people $(66.7 \%)$, and the frequency of breathing based on Respiration Rate (RR) values were normal as many as 6 people $(50 \%)$ and tachypnea as many as 6 people $(50 \%)$.

Based on Table 3, it is known that the statistical test results obtained a value of 0.049 ( $p$

Table 1. Frequency Distribution of Characteristics of Respondents in Cardiovascular Inpatients Dr. H. Moch Ansari Saleh Hospital Banjarmasin In 2018

\begin{tabular}{llcc}
\hline Characteristics of Respondents & $\mathbf{n}$ & $\%$ \\
\hline Age & 36-45 years old & 1 & 8.3 \\
& 46-55 years old & 3 & 25.0 \\
& 56-65 years old & 7 & 58.3 \\
& $>$ 65 years old & 1 & 8.3 \\
Gender & Male & 8 & 66.7 \\
& Girl & 4 & 33.3 \\
Education & Middle School / equivalent & 6 & 50.0 \\
& High school / vocational & 6 & 50.0 \\
& school / equivalent & \multicolumn{3}{c}{} \\
amount & & 12 & 100 \\
\hline
\end{tabular}

Source: Processed Primary Data , 2018

Table 2. Sodium Intake Data, Fluid Balance and Breath Frequency Based on Respiration Rate (RR) Value of Respondents in Cardiovascular Inpatients Dr. H. Moch. Ansari Saleh Banjarmasin in 2018

\begin{tabular}{llcc}
\hline \multicolumn{1}{c}{ Univariate Analysis } & $\mathbf{n}$ & $\%$ \\
\hline Sodium intake & $\begin{array}{l}\text { Adequate (sodium intake } \\
\text { of 200-400 mg) }\end{array}$ & 9 & 75.0 \\
& $\begin{array}{l}\text { More (Sodium intake> } \\
\text { Fo0 mg) }\end{array}$ & 3 & 25.0 \\
Fluid Balance & Negative & 8 & 66.7 \\
& Positive & 4 & 33.3 \\
Breath & Normal $(\leq 24 \times /$ minute) & 6 & 50.0 \\
Frequency & Tachypnea (> 24 x / & 6 & 50.0 \\
based on RR & minute) & & \\
Value & & 12 & 100 \\
amount & & & \\
\hline
\end{tabular}

Source: Processed Primary Data , 2018 
$<0.05)$ which indicates that there is a significant relationship between sodium intake and the incidence of shortness of breath based on the Respiration Rate (RR) value in CHF patients in the Cardiac Inpatient Hospital Dr. H. Moch. Ansari Saleh. Correlation value $r=0.577$ indicates a strong and positive correlation between sodium intake and the incidence of shortness of breath based on the value of the Respiration Rate (RR).

Table 4 shows that the statistical test results obtained a value of $0.01(p<0.05)$ which shows that there is a significant relationship between fluid balance and the incidence of shortness of breath based on the Respiration Rate (RR) value in CHF patients in the Cardiac Inpatient Dr. H. Moch. Ansari Saleh Hospital. Correlation value $r=0.707$ shows a strong and positive correlation between fluid balance and the incidence of shortness of breath based on the Respiration Rate (RR)

Table 3. Distribution of Respondents by Sodium Intake with Shortness of Breath based on Respiration Rate (RR) CHF Patients in Cardiovascular Inpatients Dr. H. Moch Ansari Saleh Banjarmasin in 2018

\begin{tabular}{lcccccc}
\hline \multirow{2}{*}{$\begin{array}{c}\text { Sodium } \\
\text { intake }\end{array}$} & \multicolumn{3}{c}{$\begin{array}{c}\text { Shortness of Breath based } \\
\text { on Respiration Rate (RR) }\end{array}$} & \multirow{2}{*}{ amount } \\
\cline { 2 - 5 } & \multicolumn{2}{c}{ Normal } & \multicolumn{2}{c}{ Tachypnea } & & \\
\cline { 2 - 6 } & $\mathbf{n}$ & $\%$ & $\mathbf{n}$ & $\%$ & $\mathbf{n}$ & $\%$ \\
\hline Enough & 6 & 66.7 & 3 & 33.3 & 9 & 100 \\
More & 0 & 0.0 & 3 & 100 & 3 & 100 \\
amount & 6 & 50.0 & 6 & 50.0 & 12 & 100 \\
\hline
\end{tabular}

$\rho=0.049 r=0.577 \alpha=0.05$

Source: Processed Primary Data, 2018

Table 4. Distribution of respondents according to the balance of liquids with Shortness of Breath by Respiration Rate (RR) CHF Patients at Heart Hospital Inpatient Room Dr. H. Moch Ansari Saleh Banjarmasin in 2018

\begin{tabular}{lcccccc}
\hline \multirow{2}{*}{$\begin{array}{c}\text { Fluid } \\
\text { Balance }\end{array}$} & \multicolumn{2}{c}{$\begin{array}{l}\text { Shortness of Breath based } \\
\text { on Respiration Rate (RR) }\end{array}$} & \multirow{2}{*}{ amount } \\
\cline { 2 - 5 } & \multicolumn{2}{c}{ Normal } & \multicolumn{1}{c}{ Tachypnea } & & \\
\cline { 2 - 6 } & $\mathbf{N}$ & $\%$ & $\mathbf{n}$ & $\%$ & $\mathbf{n}$ & $\%$ \\
\hline Negative & 6 & 75.0 & 2 & 25.0 & 8 & 100 \\
Positive & 0 & 0.0 & 4 & 100 & 4 & 100 \\
amount & 6 & 50 & 6 & 50 & 12 & 100 \\
\hline
\end{tabular}

$\rho=0.01 r=0.707 \alpha=0.05$

Source: Processed Primary Data , 2018

\section{DISCUSSION}

Respondents aged 56 - 65 years with a total of 7 people (58.3\%) with the majority of respondents aged 61 years who experienced Congestive Heart Failure (CHF). The distribution of Congestive Heart Failure (CHF) is known to increase at the age of 40 years and above. As a person ages he is at risk of developing heart failure due to increasing age there is a decline in heart function. The results of this study are in accordance with the theory that increasing age in a person causes natural changes in the body that affect the heart, blood vessels and hormones (8) with many guidelines recommending sodium intakes of $2.3 \mathrm{~g} /$ day or lower. These guideline thresholds are based largely on clinical trials reporting a reduction in blood pressure with low, compared with moderate, intake. However, no large-scale randomized trials have been conducted to determine the effect of low sodium intake on $\mathrm{CV}$ events. Prospective cohort studies evaluating the association between sodium intake and CV outcomes have been inconsistent and a number of recent studies have reported an association between low sodium intake (in the range recommended by current guidelines Fachrunnisa Research (2015). (9) Which examined the factors related to sleep quality in Congestive Heart Failure patients showed that the majority of respondents aged $45-60$ years were 14 respondents (43.8\%).

Gender is a matter of identity for respondents that can distinguish between respondents with one another. The results of data analysis about the data of respondents showed that the majority of respondents were men with a total of 8 people $(66.7 \%)$. This is in accordance with Hamzah's research (2016) (10)penurunan peran dalam keluarga dan pernikahan serta berkurangnya fungsi kerja dan dukungan sosial yang mereka terima. Usia dan jenis kelamin menentukan perbedaan strategi koping dalam mengatasi berbagai penurunan fungsi pada pasien gagal jantung. Penelitian bertujuan untuk menganalisis hubungan antara usia dan jenis kelamin dengan kualitas hidup pada penderita gagal jantung di RS PKU Muhammadiyah Yogyakarta. Penelitian kuantitatif korelatif dengan pendekatan cross sectional. Penelitian melibatkan 60 penderita gagal jantung yang diambil dengan teknik purposive 
sampling. Kualitas hidup diukur dengan kuesioner WHOQOL (World Health Organization's Quality of Life Said that there were 36 people $(60 \%)$ of male $\mathrm{CHF}$ patients who were undergoing treatment, while 27 female patients (40\%). Research conducted by Inamdar 2016 also showed that the majority of male respondents were 57 people (52\%) and female respondents were 53 people (48\%). Men are more susceptible to heart disease. According to Dr. Basuni Radi, SpJP $(K)$, men are more prone to heart disease because of irregular lifestyles such as smoking, drinking alcoholic beverages, and hormonal factors (11)chronic health problems, psychological disorders, increased maintenance costs each year up to early death. 2.8 million people die each year due to obesity. The increasing prevalence of obesity in adolescents allegedly associated with lifestyle changes include the decline in physical activity and increased consumption of snacks. The objective of the research is to determine the difference of physical activity and snack consumption in adolescent obesity in urban and rural areas in the district of Bantul. This study used a case control study design, with a population of high school teenagers both public and private. Cases are obese adolescents who were diagnosed at screening, while the control is not obese adolescents. Data analysis included univariable consist of frequency distribution, bivariable consist of chi-square and t-test and also logistic regression test for mulitivariabel analysis. The result shows that the bivariate analysis showed significant association between physical activity and obesity with a value ( $\mathrm{P}<0.05$; OR $4.26(95 \% \mathrm{Cl}: 1.61$ to 12.06 Risk factors for congestive heart failure in women tend to be lower than men because women have the hormone estrogen which can produce High Density Lipoprotein (HDL). But in the condition of a decrease or loss of estrogen levels in women at menopause causes increased levels of triglycerides and a decrease in total fat, so that menopausal women are more at risk of heart disease (12)

Based on the results of the study note that respondents have a junior high school / equivalent level of 6 people $(50 \%)$ and high school / high school / equivalent of 6 people $(50 \%)$. This result is in line with research conducted by Aliffian in Bertalina (2017) also showing that respondents have the highest level of education at the high school level. This is in accordance with the opinion of Discher et al., (2009) (13) Which states that the level of education will affect the health of patients with congestive heart failure. Patients with higher education level will be able to make efforts to improve their health optimally compared to patients with low education. (14)

A sodium intake respondents in this research was quite as much as 9 people $(75 \%)$. Sodium is one of the many minerals found in extracellular electrolyte fluid (outside the cell), has the effect of holding water, serves to maintain fluid in the body, activates enzymes, as conduction of nerve impulses. Decreased cardiac output increases ADH and triggers sodium and water retention to meet cardiac volume and output. The aldosteron hormone also increases thereby increasing sodium and fluid retention with the aim of increasing venous return. The level of total sodium in the body generally increases even though the level of sodium in the serum shows a decrease. That is common in advanced heart failure conditions. Therefore, sodium restriction and fluid retention must be performed in patients with heart failure. (15) Recommendations for sodium administration vary, the most common recommendation being that sodium restriction reaches <2000 mg (2 gr), but recommendations can range from 2000 - $2400 \mathrm{mg} /$ day. Restrictions depend on the severity of fluid retention and response to diuretics. (1)

Statistical test results showed a significant positive relationship between sodium intake and the occurrence of shortness of breath based on the Respiration Rate (RR) value of CHF patients with a value of $p=0.049$. A positive relationship $(r=0.577)$ can be interpreted that the higher the intake of sodium the higher the incidence of shortness of breath in CHF patients. The results of this study are in line with research conducted by He et al., In Masyitoh (2013). (16) which conducted a study with $679 \mathrm{CHF}$ patients who were overweight and often experienced shortness of breath. Patients consume an average 
of $113.6 \mathrm{mmol} /$ day of salt. After being given a low salt diet program for 6 months, the results showed that salt consumption decreased to $50.2 \mathrm{mmol} /$ day accompanied by a significant decrease in shortness of breath. According to Hartono (2004). (17) limiting intake of salt (sodium) to 2-3 grams of sodium per day (excessive salt consumption can cause fluid retention so that it adds to the symptoms of edema that is common in congestive heart failure).

On the first day in observation of 12 respondents, it was known that urine expenditure for 24 hours the respondent only ranged from 300 to $900 \mathrm{ml}$ per 24 hours with an average urine output for 24 hours was $562 \mathrm{ml}$. Heart disorders can cause fluid and electrolyte imbalances and result in kidney disorders. When blood flow to the kidneys decreases due to the ability of the heart pump to decrease, the body will accumulate fluid and sodium, resulting in fluid retention and fluid overload (hypervolemia). Furthermore, this condition can cause pulmonary edema. Normally, urine will be released in an amount sufficient to balance fluids and electrolytes, acid and base levels in the body. If a lot of fluid intake, the kidneys will filter more fluid and hold ADH so that urine production will increase. Conversely, in a state of lack of fluids, the kidneys will reduce urine production in various ways. Among them are increased tubular reabsorption, sodium retention, and rennin release. If the kidneys are damaged, the ability of the kidneys to carry out regulation will decrease. Therefore, when kidney disorders occur (for example kidney failure) individuals can experience oliguria (urine production of less than $400 \mathrm{ml} / 24$ hours) to anuria (urine production of less than $200 \mathrm{ml} /$ hour). (12)

The results of this study indicate that the fluid balance of respondents classified as negative as many as 8 people $(66.7 \%)$ are in a relatively normal respiratory state. This is a response from the use of diuretic therapy. Generally, loop-blocking diuretics, especially spironolactone, are the treatment of choice used in therapeutic treatments for heart failure patients. The combination of diuretic administration along with fluid and sodium restriction has been shown to reduce the incidence of re-hospitalization in compensated heart failure patients .(18)
Based on the results of statistical tests found that there is a significant positive relationship between fluid balance and the occurrence of shortness of breath in CHF patients with $p=0.01$. This positive relationship ( $r=0.707$ ) can be interpreted that the more positive fluid balance it will increase the incidence of breathlessness in patients with $\mathrm{CHF}$. This is consistent with case study research conducted by Lestari (2013) (19)which includes disease-related malnutrition (DRM of $4 \mathrm{CHF}$ patients given fluid restriction ranging from 100$1500 \mathrm{ml}$ or $80 \%$ of total fluid requirements, diuresis within normal limits with fluid balance maintained negative and results during treatment shortness of breath in patients reduced. According to research conducted by Vittoria in Austaryani (2012) 4, for patients with heart failure with severity and limited physical activity according to NYHA Class II to IV classification, diuretic drug therapy can be given as its implementation so as to increase the release of water and sodium salt in the body client and can cause a significant decrease in fluid volume, which is followed by a decrease in shortness of breath.

\section{CONCLUSIONS AND RECOMMENDATIONS}

Based on the results of this study, there is a significant positive relationship between sodium intake and fluid balance on the occurrence of shortness of breath based on the Respiration Rate (RR) value of Congestive Heart Failure (CHF) patients at RSUD Dr. H. Moch Ansari Saleh Banjarmasin in 2018. The results of this study are expected to increase knowledge and better control the patient's lifestyle by reducing preserved food, foods processed using salt and flavorings and controlling fluid balance by paying attention to intake (both from drinks, food, and infusion fluids) and discharge of fluids by see 24 -hour urine volume. Efforts to control the occurrence of shortness of breath in patients with Congestive Heart Failure (CHF related to CHF management such as education and counseling related to $\mathrm{CHF}$ disease, management of a low-salt heart diet and periodic fluid balance to each patient and family. For other researchers to further develop variables 
such as potassium intake that affects other signs or symptoms in patients with Congestive Heart Failure (CHF) and as input for efforts to improve nutrition and improve healthy behavior.

Results $p$ enelitian is expected in $p$ kan da $p$ at increasing knowledge and better control the pattern of life of patients by reducing preserved foods, processed foods use salt and flavorings as well as controlling the fluid balance by paying attention to the intake (both from beverages, food, as well as intravenous fluids ) and discharge by looking at 24-hour urine volume. Efforts in controlling the occurrence of shortness of breath in patients with Congestive Heart Failure (CHF) must always be optimized by the hospital by increasing health programs related to $\mathrm{CHF}$ management such as education and counseling related to $\mathrm{CHF}$ disease, management of a low-salt heart diet and regular fluid balance to each patient and family. For other researchers to further develop variables such as potassium intake that affects signs or other symptoms in patients with Congestive Heart Failure (CHF) and as input for efforts to improve nutrition and healthy behaviors.

\section{REFERENCES}

1. Smeltzer S. . Keperawatan Medical Bedah. 10th ed. Jakarta: EGC : Jakarta., 2001; 2001. xxii,716 HIm.il.,27cm1133.

2. Anita strom KLA. Being "on the alert" and "a forced volunteer": a qualitative study of the invisible care provided by the next of kin of patients with chronic heart failure. Multi discip Healthc. 2015;8:271-277.

3. RSUD Dr. H. Moch. Ansari Saleh. Medical Record Data . Banjarmasin. 2017.

4. Didik Aji Asmoro. Asuhan Keperawatan pada Pasien Congestive Heart Failure (CHF) denganPenurunan Curah Jantung Melalui Pemberian Terapi Oksigen di RuangICU PKU Muhammadyah Gombong. [Internet]. Sekolah Tinggi IImu Kesehatan Muhammadiyah; 2017. Available from: http://elib.stikesmuhgombong. ac.id/id/eprint/668
5. Imelda Suratinoyo, Julia Rottie GM. Relationship of anxiety levels with coping mechanisms in congestive heart failure patients in CVBC Room (Cardio Vascular Brain Center) on the third floor in DR. RD Regional Hospital, Manado. Nurs Ejournal, 4 (1), 1 [Internet]. 2016;4(1). Available from: https://www.neliti. com/publications/105404/hubungan-tingkatkecemasan-dengan-mekanisme-koping-padapasien-gagal-jantung-kon

6. (UK) NCC for CC. Chronic Heart Failure: National Clinical Guideline for Diagnosis and Management in Primary and Secondary Care. In: Chronic Heart Failure National Clinical Guideline for Diagnosis and Management in Primary and Secondary Care NICE Clinical Guidelines, No 5 National Collaborating Centre for Chronic Conditions (UK) London: Royal College of Physicians (UK); 2003 ISBN-10. London: Royal College of Physicians (UK); 2003; 2003.

7. Kasron. Buku Ajar Gangguan sistem Kardiovaskule. yogyakarta: Nuha Medika; 2012.

8. M.J. O'Donnell *. Fluid balance concepts in medicine: Principles and practice. Eur Hear Journal, [Internet]. 2013;34(14):1034-40. Available from: https://doi.org/10.1093/eurheartj/ ehs409

9. Fachrunnisa ', Sofiana 'Nurchayati A'. Faktorfaktor yang Berhubungan dengan Kualitas Tidur pada Pasien Congerstive Heart Failure. Online Mhs [Internet]. 2016;2(2):1094-105. Available from: https://jom.unri.ac.id/index.php/JOMPSIK/ article/view/8273

10. Rori Hamzah; Widaryati; Darsih. Hubungan Usia dan Jenis Kelamin dengan Kualitas Hidup pada Penderita Gagal Jantungdi RS PKU Muhammadyah Yogyakarta. Students J. 2016;

11. Mellia Silvy Irdianty. Physucal Activities and Snack Consumptionof Obese Adolescents in Bantul Yogyakarta. In: Sabar Santoso, S.Pd.,APP. MK, editor. THE 4th International Conference On Health Science 2017. Yogyakarta: Health Polytechnic of Ministry of Health in Yogyakarta 2017; 2017. p. 60. 
12. melda Suratinoyo, Julia Rottie GM. No TitleHubungan Tingkat Kecemasan Dengan Mekanisme Koping Pada Pasien Gagal Jantung Kongestif Diruangan Cvbc (Cardio Vaskuler Brain Centre) Lantai III Di Rsup. Prof. Dr. R. D. Kandou Manado. ejournal Keperawatan Vol 4 Nomor 1, Mei 2016 [Internet]. 2016;4(1). Available from: https://www.neliti. com/publications/105404/hubungan-tingkatkecemasan-dengan-mekanisme-koping-padapasien-gagal-jantung-kon

13. Discher $C L$, Klein D, Pierce L, Levine AB, Levine TB. Heart Failure Disease Management: Impact on Hospital Care, Length of Stay, and Reimbursement. Congest Hear Fail [Internet]. 2003 Mar;9(2):77-83. Available from: http://doi. wiley.com/10.1111/j.1527-5299.2003.01461.x

14. Lloyd-Jones D, Adams RJ, Brown TM, Carnethon M, Dai S, De Simone G, et al. Heart Disease and Stroke Statistics-2010 Update. Circulation [Internet]. 2010 Feb 23;121(7). Available from: https://www.ahajournals.org/doi/10.1161/ CIRCULATIONAHA.109.192667
15. Yani A, Nugraha GI, DH DM. Analysis of Nutrition Care Chronic Renal Failure Patients with Health Technology Assessment. J Kesehat Masy [Internet]. 2017 Jul 28;13(1):96-105. Available from: https://journal.unnes.ac.id/nju/index.php/ kemas/article/view/4367

16. Masyitoh AP. Analisis Modifikasi Gaya Hidup pada Pasien dengan Pasien dengan Congestive Heart Failure (CHF) di RS PKU Muhammadyah. [Internet]. 2013. Available from: http://repository. umy.ac.id/handle/123456789/6678

17. Andry Hartono. Terapi gizi dan diet rumahsakit. 2nd ed. Ester M, editor. 2006. 322 p.

18. Salvatore Paterna, Parrinello Gaspare, Sergio Fasullo, Filippo M Sarullo PDP. Normalsodium diet compared with low-sodium diet in compensated congestive heart failure: is sodium an old enemy or a new friend? Clin Sci 2008. 2008;114:221-30.

19. T. Cederholm a *, B RB, , P. Austin c Y. ESPEN guidelines on definitions and terminology of clinical nutrition. Clin Nutr. 2017;6:49-64. 